Pesq. Vet. Bras. 37(3):210-214, março 2017

DOI: $10.1590 / \mathrm{S} 0100-736 \mathrm{X} 2017000300002$

\title{
Retrospective analysis of cattle poisoning in Argentina $(2000-2013)^{1}$
}

\author{
Juan A. García²*, Germán J. Cantón², Bernardo L. García3, Juan F. Micheloud4, \\ Carlos M. Campero ${ }^{5}$, Ernesto J.A. Späth ${ }^{2}$ and Ernesto R. Odriozola ${ }^{2}$
}

\begin{abstract}
García J.A., Cantón G.J., García B.L., Micheloud J.F., Campero C.M., Späth E.J.A. \& Odriozola E.R. 2017. Retrospective analysis of cattle poisoning in Argentina (2000 2013). Pesquisa Veterinária Brasileira 37(3):210-214. Estación Experimental Agropecuaria Balcarce (EEA), Instituto Nacional de Tecnología Agropecuaria (INTA), Ruta Nacional $226 \mathrm{Km}$ 73,5, (7620) Balcarce, Buenos Aires, Argentina. E-mail: garciajuanagustin@hotmail.com

A retrospective analysis (2000 to 2013) of cattle poisoning caused by toxic plants and other compounds was carried out in the Pampas region of Argentina by the Animal Health Group of INTA-EEA, Balcarce. During this period, 1263 reports of diseases of different etiologies (infectious, parasitic, toxic, metabolic and miscellaneous) were recorded in cattle, by collecting anamnestic, clinical and pathological information. A toxic etiology was diagnosed in $21.1 \%$ of these reports. Iatrogenic poisoning caused by ionophores was the most frequently recorded etiology. Consumption of toxic plants (Wedelia glauca, Solanum glaucophyllum, among others), mycotoxins (Claviceps purpurea, Claviceps paspali, Epichloë coenophiala, among others), and plants producing cyanide and nitrates/nitrites were also commonly diagnosed. The high frequency of toxic episodes and the difficulties in their diagnosis by practitioners in our livestock production systems emphasizes the importance of this report.
\end{abstract}

INDEX TERMS: Poisoning, cattle, Argentina.

\section{INTRODUCTION}

Poisoning associated with the consumption of toxic plants or the iatrogenic administration of chemical compounds generates either direct or indirect severe economic losses in livestock production systems worldwide (Assis et al. 2009, Rivero et al. 2011b). Direct losses are associated with clinical manifestation of the disease, which can achieve high mortality rates, as well as sub-clinical manifestations, with decreased meat and milk production. Indirect losses include control and management of toxic plants, practices expenses, treatments to clinically-affected ani-

\footnotetext{
${ }^{1}$ Received on September 18, 2015

Accepted for publication on September 30, 2016

${ }^{2}$ Estación Experimental Agropecuaria Balcarce (EEA), Instituto Nacional de Tecnología Agropecuaria (INTA), Ruta Nacional $226 \mathrm{Km} \mathrm{73,5,}$ (7620) Balcarce, Buenos Aires, Argentina. *Corresponding author: garciajuanagustin@hotmail.com

${ }^{3}$ Actividad privada.

${ }^{4}$ Área de Investigación de Sanidad Animal-IIACS Salta/INTA, Ruta 68 Km 72, (4400) Cerrillos, Salta, Argentina.

${ }^{5}$ Investigador Retirado EEA Balcarce, INTA, Argentina.

* Dirección actual: Centro Universitario Regional del Este, Universidad de la República, Treinta y Tres 33000, Uruguay.
}

mal, laboratory expenses, professional fees, and replacement of dead animals (Riet-Correa \& Medeiros 2001). Etiological diagnosis of poisoning episodes is often imprecise, mainly due to the nonspecific manifestation of clinical signs. Failures in the recognition of toxic plants may also hinder diagnosis. Some poisonous plants remain toxic in hay and bales. Other toxins have a cumulative effect and, therefore, poisoning is clinically detected several weeks or months after their consumption has ceased (Odriozola et al. 1994). Furthermore, poisoning by some plants can have different clinical manifestations, depending on the category of the affected animal (Riet-Correa et al. 2013). In addition, mistakes in the administration of enteric or parenteral additives may cause significant mortality (Potter et al. 1984, Oliveira-Filho et al. 2010, Rivero et al. 2011a). There is limited regional information about the incidence of toxic episodes and associated losses in livestock. Here we present a retrospective study of poisonings occurring in cattle recorded by the Specialized Veterinary Diagnostic Service (SDVE) of National Institute of Agricultural Technology (INTA) in Balcarce (Argentina), with the aim of establishing the incidence and determining the losses generated by these diseases. 


\section{MATERIALS AND METHODS}

Poisoning episodes detected and recorded in commercial beef and dairy cattle farms located in different provinces of Argentina by SDVE of EEA-INTA Balcarce were retrospectively analyzed. Data included records obtained from January 2000 to December 2013. Anamnestic, epidemiological, clinical and pathological information along with complementary techniques were used to obtain the etiological diagnosis. The year-period effect was analyzed using the GLIMMIX variance analysis procedure (Generalized linear mixed models) in SAS (SAS Institute Inc. 2008), with Poisson distribution.

\section{RESULTS AND DISCUSSION}

During this study period, 1263 bovine cases submitted for diagnosis, were included. Most of the farms were located in Buenos Aires province (96\%) (Fig.1). Of all the analyzed reports, poisoning etiology was diagnosed in 267 outbreaks $(21.1 \%)$. Other bacterial (20\%), metabolic (14\%), miscellaneous (9\%), parasitic (8\%) and viral (8\%) pathologies were diagnosed. No etiological diagnosis was achieved in $20 \%$ of the analyzed cases. Beef and dairy farms represented $95.7 \%$ and $4.3 \%$ of total outbreaks, respectively. Four different beef production systems were distinguished: cow-calf (C) (62\%), rebreeding (R) (8\%), feedlot (F) (13\%) or winter fattening $(\mathrm{W})(17 \%)$.

Consumption of toxic plants and mycotoxins were the most common causes, representing 31 out of the 40 different etiologies diagnosed in this study. The highest frequency of poisoning episode reports was observed in cowcalf herds (62\%), mainly affecting cows (42.2\%) and calves (18.5\%). Diagnosed etiologies, farm systems and categories of affected animals are summarized in Table 1. Seasonal distribution of the different diagnosed toxic etiologies is summarized in Table 2.

The frequency of poisonings showed no significant differences between seasons $(p=0.08)$. A similar result was obtained from the separate analyses of poisonings due to intake of toxic plant species and mycotoxins $(n=179)$, with no statistical differences between seasons $(\mathrm{p}=0.06)$.

This is the first report providing local information on poisoning outbreaks in cattle from Argentina, complementing other regional studies (Riet-Correa et al. 2009, Rivero et al. 2011b). These studies demonstrate that toxic outbreaks

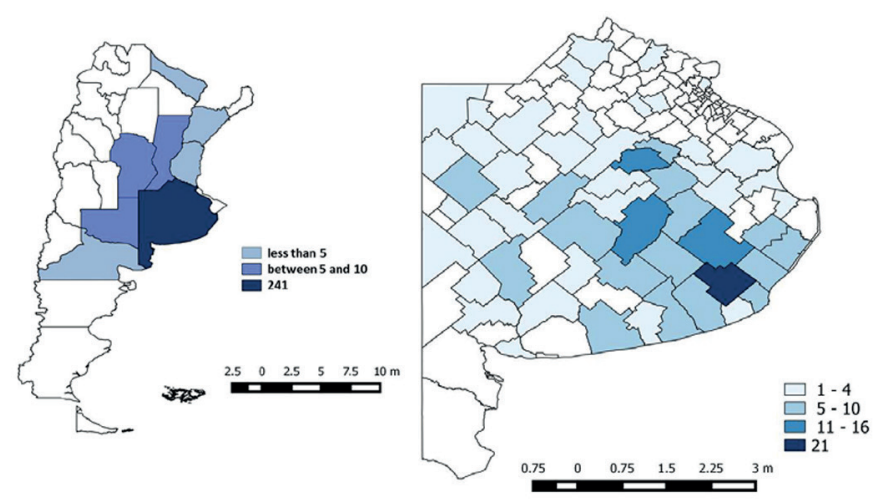

Fig.1. Geographical location and frequency of poisoning episodes recorded in cattle. (Argentina (left) and Buenos Aires province (right.) map.) in livestock production systems are very serious problems that cause major economic impact on extensive grazing systems, particularly in Uruguay, Brazil and Argentina (Riet-Correa \& Medeiros 2000).

The animal groups most commonly affected with toxic episodes were breeding (Cow-Calf) herds, probably because these are the most common production systems in the area of influence of SDVE of EEA-INTA Balcarce. These extensive natural grazing systems are often degraded by innadecuate grazing (Rearte 2007, Späth \& Becker 2012), thus favoring the growth of toxic plants.

Among the different toxic causes diagnosed during the study period, overdose of ionophores was the most prevalent, mainly in young cattle raised in feedlot systems during winter and spring. These additives, including monensin and lasalocid, are used to increase feed conversion rates and therapeutically as coccidiostats, among other uses (Callaway et al. 2003). However, in feedlot systems, supplement addition is the main cause of diagnosed toxicity (Van Vleet et al. 1983), usually as the result of human error in formulating rations and dosage (Potter et al. 1984).

Nitrate-nitrite poisoning was recorded in cattle after being exposed to particular climatic conditions, characterized by forage water deprivation followed by abundant rainfall, as previously reported (Binta et al. 2012).

Phalaris spp. was the most frequently recorded neurotoxicant, clinically characterized as tremorgenic syndrome (Riet-Correa et al. 2013) that is indistinguishable from other plant poisonings: Cynodon dactylon (parasitized by the fungus Claviceps cynodontis) (Uhlig et al. 2009), Paspalum spp. (parasitized by Claviceps paspali) and Lolium perenne (parasitized by Neotyphodium lolii) (Cole et al. 1977, Towers 2006). Clinical signs are characterized by tremors and head nodding, cerebellar ataxia, uncoordinated gait, hypermetria, signs exacerbated after excitement of the affected animals (Riet-Correa et al. 2013). Mortality rates recorded in tremorgenic syndrome due to the consumption of the previously mentioned toxic plants were lower than $1 \%$, with the exception of Phalaris poisoning, which caused 5\% mortality, as previously reported (Odriozola et al. 1991). Phalaris poisoning was sporadically recorded. Indole alkaloid production by Phalaris spp. would occur under certain environmental conditions (Baal et al. 1978). Eleven out of the 12 Phalaris poisoning outbreaks analyzed in this study occurred during spring-summer; this finding is in disagreement with reports from Uruguay, which indicate that most cases occurred during summer-autumn (Riet-Correa 1993). Several species of Phalaris are associated with cattle poisoning (Sousa \& Irigoyen 1999). Phalaris. angusta is a natural grass widely distributed in our region and the main species identified in the Argentine outbreaks (Cantón et al. 2010). As previously mentioned, Paspalum spp. are also tremorgenic species. Clinical Paspalum spp. poisoning usually occurs when the plant is seeded; therefore, outbreaks occurred mainly during mid-autumn (Cole et al. 1977), as detected in the current study. $C$. dactylon poisoning was frequently clinically detected in grazing cattle during autumn-winter, in coincidence with the first frost of the season (late autumn - early winter), as previously mentioned (Odriozola et al. 1998, Riet-Correa et al. 2013). 
Poisoning by organophosphates in cattle is usually associated with the application of pour-on solutions and contaminated food intake (Oliveira-Filho et al. 2010). The cases reported in this study were related to insecticide overdose (ethion, chlorpyrifos, fenthion), and ingestion of food/pastures or water contaminated with agricultural pesticides (malathion, chlorpyrifos with cypermethrin, dimethoate). Organophosphorus compound toxicity varies with the drug

Table 1. Poisoning etiologies diagnosed in cattle during 2000-2013 ( $n=267)$, including number of outbreaks, farm systems and affected animal categories

\begin{tabular}{|c|c|c|c|c|c|c|c|c|c|c|c|}
\hline \multirow[t]{2}{*}{ Etiology } & \multirow[t]{2}{*}{$\begin{array}{l}\text { Number of } \\
\text { outbreaks }\end{array}$} & \multicolumn{5}{|c|}{$\begin{array}{c}\text { Farm systems }(*) \\
\text { (frequency of outbreaks) }\end{array}$} & \multicolumn{5}{|c|}{$\begin{array}{c}\text { Animal category }\left({ }^{* *}\right) \\
\text { (frequency of outbreaks) }\end{array}$} \\
\hline & & $\mathrm{C}$ & $\mathrm{R}$ & $\mathrm{W}$ & $\mathrm{F}$ & $\mathrm{D}$ & $\mathrm{C}$ & $\mathrm{H}$ & $\mathrm{Ca}$ & $\mathrm{B}$ & S \\
\hline \multicolumn{12}{|l|}{ Cardiac toxicants: } \\
\hline Ionophores & 46 & 5 & 6 & 10 & 24 & 1 & 1 & 7 & 8 & - & 30 \\
\hline Nerium oleander $\left({ }^{* * *}\right)$ & 1 & 1 & - & - & - & - & 1 & 1 & - & - & - \\
\hline \multicolumn{12}{|l|}{ Systemic toxicants: } \\
\hline Solanum glaucophyllum & 24 & 21 & 1 & 1 & 1 & - & 21 & 1 & - & - & 2 \\
\hline Epichloë coenophiala & 14 & 11 & - & 1 & - & 2 & 12 & - & 1 & - & 1 \\
\hline Claviceps purpurea & 14 & 7 & - & 4 & 2 & 1 & 3 & 3 & 2 & - & 6 \\
\hline Nitrogenous compounds & 7 & 2 & 2 & - & 3 & - & 2 & 2 & - & - & 3 \\
\hline Vicia spp. & 3 & - & 2 & - & - & 1 & 2 & 1 & - & - & - \\
\hline Salt poisoning $(* * *)$ & 2 & 2 & - & - & - & - & 2 & 1 & - & - & - \\
\hline \multicolumn{12}{|l|}{ Hepatic toxicants: } \\
\hline \multicolumn{12}{|l|}{ Acute hepatotoxicity: } \\
\hline Wedelia glauca & 15 & 7 & 2 & 5 & 1 & - & 5 & 1 & 4 & 1 & 4 \\
\hline Cestrum parqui( $\left.{ }^{* * *}\right)$ & 8 & 7 & - & 1 & - & - & 4 & 2 & 2 & - & 1 \\
\hline Copper & 5 & 1 & - & 3 & 1 & - & - & - & 2 & - & 3 \\
\hline Xanthium spp. & 3 & 3 & - & - & - & - & 2 & -1 & 1 & - & - \\
\hline Blue-green alga $(* * *)$ & 3 & 3 & - & - & - & - & 1 & 2 & 1 & 1 & - \\
\hline Unknowna $(* * *)$ & 2 & 2 & - & - & - & - & 2 & - & 1 & - & - \\
\hline \multicolumn{12}{|l|}{ Chronic hepatotoxicity: } \\
\hline Senecio spp. & 8 & 7 & - & - & 1 & - & 7 & - & - & - & 1 \\
\hline Unknown $^{\mathrm{a}}$ & 6 & 5 & - & - & - & 1 & 4 & 2 & - & - & - \\
\hline \multicolumn{12}{|l|}{ Hepatogenous Photosensitizers: } \\
\hline Pithomyces chartarum & 12 & 8 & 1 & 3 & - & 2 & 6 & 2 & 3 & - & 1 \\
\hline Unknown ${ }^{\mathrm{a}}$ & 3 & 2 & - & - & - & 1 & 1 & 2 & - & - & - \\
\hline Myoporum laetum & 2 & 2 & - & - & - & - & - & 1 & - & 1 & - \\
\hline Kochia scoparia & 2 & 1 & - & 1 & - & - & 1 & - & - & - & 1 \\
\hline \multicolumn{12}{|l|}{ Neurotoxicants: } \\
\hline Phalaris spp. & 12 & 8 & 2 & 2 & - & - & 3 & 3 & 5 & - & 1 \\
\hline Claviceps paspali $(* * *)$ & 10 & 8 & - & 2 & - & - & 5 & - & 3 & 1 & \\
\hline Claviceps cynodontis (***) & 9 & 8 & - & 1 & - & - & 7 & - & 2 & - & 2 \\
\hline Organophosphorus compounds & 9 & 3 & 1 & 3 & 1 & 1 & 2 & - & 3 & 1 & 3 \\
\hline Stenocarpella maydis $(* * *)$ & 8 & 8 & - & - & - & - & 6 & 1 & 1 & 1 & - \\
\hline Neotyphodium lolii (***) & 2 & 2 & 2 & - & - & - & 1 & 1 & 1 & - & - \\
\hline Condalia microphila & 2 & 2 & - & - & - & & - & - & 2 & - & - \\
\hline Solanum bonariense & 1 & 1 & - & - & - & - & 1 & - & - & - & - \\
\hline Organochlorine pesticides & 1 & 1 & - & - & - & - & - & - & 1 & - & - \\
\hline Abamectin & 1 & 1 & - & - & - & - & - & - & 1 & - & - \\
\hline \multicolumn{12}{|l|}{ Hematic toxicants: } \\
\hline Cyanide $(* * *)$ & 4 & 2 & 1 & 1 & - & - & 2 & 1 & 1 & - & 2 \\
\hline Nitrate/nitrite & 3 & 1 & 1 & 1 & - & - & 1 & - & 1 & - & 1 \\
\hline Dicumarol & 1 & - & - & 1 & - & - & - & - & 1 & - & - \\
\hline \multicolumn{12}{|l|}{ Respiratory toxicants : } \\
\hline Tryptophan & 1 & 7 & - & - & - & 1 & 8 & - & - & - & - \\
\hline \multicolumn{12}{|l|}{ Dermal toxicants: } \\
\hline \multicolumn{12}{|l|}{ Primary photosensitization: } \\
\hline Unknown ${ }^{\mathrm{a}}$ & 6 & 3 & 1 & 1 & - & 1 & 2 & - & 3 & - & 1 \\
\hline Toxicants that affect gastrointestir & & & & & & & & & & & \\
\hline Baccharis coridifolia & 4 & 3 & - & 1 & - & - & - & 3 & - & - & 1 \\
\hline Asclepias mellodora $\left.{ }^{* * *}\right)$ & 1 & 1 & - & - & - & - & 1 & 1 & - & - & - \\
\hline Renal toxicants: & & & & & & & & & & & \\
\hline Chenopodium album & 2 & 1 & - & - & 1 & - & 1 & - & - & - & 1 \\
\hline Beta vulgaris & 1 & 1 & - & - & - & - & 1 & - & - & - & - \\
\hline Amaranthus hybridus ${ }^{* * *}$ ) & 1 & - & 1 & - & - & - & - & 1 & - & - & 1 \\
\hline Teratogens: & & & & & & & & & & & \\
\hline Conium maculatum & 1 & 1 & - & - & - & - & - & 1 & - & - & - \\
\hline
\end{tabular}

$\bar{a}$ No etiological diagnosis were achieved, although anamnestic, clinical, pathological and complementary laboratory results suggest a toxic origin.

$\left(^{*}\right) \mathrm{D}=$ dairy farm, $\mathrm{W}=$ wintering, $\mathrm{C}=$ cow-calf, $\mathrm{R}=$ rebreeding, $\mathrm{F}=$ feedlot.

$\left.{ }^{* *}\right) \mathrm{C}=$ cow, $\mathrm{H}$ : heifer, $\mathrm{Ca}=$ calf, $\mathrm{B}$ : bull, $\mathrm{S}=$ steer.

$(* * *)$ Various animal categories affected in the toxic outbreak. 
Table 2. Seasonal frequency of main toxic etiologies diagnosed in cattle

\begin{tabular}{lcccc}
\hline Etiology & Summer & Autumn & Winter & Spring \\
\hline Ionophores & 6 & 7 & 16 & 17 \\
Phalaris spp. & 4 & 0 & 1 & 7 \\
Paspalum spp. & 0 & 8 & 1 & 1 \\
Cynodon dactylon & 0 & 5 & 3 & 1 \\
Organophosphorus & 4 & 2 & 1 & 2 \\
Stenocarpella maydis & 0 & 4 & 4 & 0 \\
Solanum glaucophyllum & 5 & 12 & 5 & 2 \\
Epichloë coenophiala & 3 & 2 & 1 & 8 \\
Claviceps purpurea & 11 & 2 & 10 & 2 \\
Wedelia glauca & 5 & 5 & 1 & 4 \\
Cestrum parqui & 1 & 3 & 0 & 4 \\
Senecio spp. & 0 & 0 & 1 & 7 \\
Pithomyces chartarum & 1 & 6 & 4 & 1 \\
Tryptophan & 1 & 2 & 3 & 2
\end{tabular}

used, dosage, application route and category of the affected animal (Meerdink 1989). Young cattle are the most susceptible, as observed in the cases included in this report. Different clinical features were recorded in the outbreaks analyzed (Johnson 1975, Radostits 2007a).

Mycotoxicosis caused by Stenocarpella maydis occurs when cattle is fed with infected maize during autumn-winter after water stress conditions as other authors described (Kellerman et al. 1993, Riet-Correa et al. 1993, Odriozola et al. 2005).

One of the main causes of economic losses in Argentine beef systems is enzootic calcinosis due to Solanum glaucophyllum ingestion, characterized by a chronic wasting clinical disease (Gimeno 2001). Eighty-five percent of enzootic calcinosis episodes reported in this study affected beef cows after chronic intake of S. glaucophyllum for several years, with an unusual episode having been recorded in steers fed with hay contaminated with S. glaucophyllum (Micheloud et al. 2012).

Dysthermic syndrome has been associated with the consumption of Claviceps purpurea-parasitized grasses (Schneider et al. 1996) or Epichloë coenophiala (formerly Neotyphodium coenophialum)-infected tall fescue (Porter 1995). Clinical presentation of ergot alkaloid toxicosis produced by these fungi can be affected by environmental factors such as temperature, with high temperatures causing dysthermic ergostism and low temperatures causing gangrenous ergotism (Radostits 2007b, Jessep et al. 1987). These mycotoxicoses are also clinically associated with reduced reproductive performance (Porter \& Thompson 1992, Campero 1996), which was noticed in several of the recorded episodes in this report. These results are consistent with those reported in seasons with favorable climatic conditions for $C$. purpurea growth and plant colonization; in addition, inadequate animal management practices are usually mentioned as predisposing factors for a high mortality rate associated with dysthermic syndrome in cattle, which is in agreement with several reports included in this retrospective study (Jessep et al. 1987, Schneider et al. 1996).

Acute hepatotoxicoses were commonly associated with the consumption of Wedelia glauca, Myoporum laetum, Xanthium spp. and Cestrum parqui. They are clinically and pathologically similar to blue-green algae toxicosis or acute copper poisoning (Burrows \& Tyrl 2001, Stalker \& Hayes 2007). Although acute copper toxicosis, can vary with chronicity of exposure, from nonspecific acute centrilobular necrosis to colangiohepatitis with periportal fibrosis (Cullen \& Stalker 2016), in all the present cases, acute centrilobular necrosis was seen, due to excessive parenteral suplementation. Wedelia glauca poisoning was the most frequently recorded intoxication in cattle, mainly during autumn (plant vegetative stage) or spring-summer (reproductive stage) (Micheloud \& Odriozola 2012). Unusual events may occur when cattle are fed with contaminated hay. Other acute hepatotoxic episodes were not etiologically diagnosed, although they were associated with intake of maize contaminated with Ustilago maydis and Fusarium verticillioides. However, this finding could not be reproduced experimentally and there are no previous records in the literature supporting this finding.

Facial eczema due to the ingestion of the mycotoxin sporidesmin produced by the saprophytic fungus Pithomyces chartarum was commonly diagnosed. Sporidesmin may cause hepatotoxicity, triggering secondary photosensitization (Nelly 1985). This etiology showed a marked seasonality, as previously reported (Dingley 1962, Towers 1994, Riet-Correa et al. 2013).

Most of the poisoning episodes in cattle recorded by SDVE of EEA-INTA Balcarce during the period 2000-2013 were directly or indirectly associated with incorrect management procedures, as previously described (Botha \& Penrith 2008, Riet-Correa et al. 1993). Most of these intoxications may result in high mortality rates. However, many other poisonings are subclinical and poorly diagnosed, but they can produce important economic losses.

\section{CONCLUSIONS}

According to these findings, poisoning episodes in cattle from our region represent the main reason for consultation in veterinary practice. They are one of the main causes of economic losses in the cattle industry, which is consistent with other regional studies.

Changes in farm management strategies occurred in the last decades in Argentina, which could partially explain the high frequency of poisoning episodes.

This study analyzes for the first time the main poisoning etiologies in cattle in different production systems of the Pampas region of Argentina.

Improvement in the recognition of toxic plants and the conditions in which they become a hazard, as well as the correct use of therapeutic/preventive compounds is important in order to prevent future economic losses.

Acknowledgements.- The authors thank Adriana Cano and Virginia Frade from EEA-INTA Balcarce (Argentina) in the elaboration of maps and statistical analyses.

Conflict of interest statement.- The authors have no competing interests.

\section{REFERENCES}

Assis T.S., Medeiros R.M.T., Araújo J.A.S., Dantas A.F.M. \& Riet-Correa F. 2009. Intoxicações por plantas em ruminantes e equídeos no Sertão Paraibano. Pesq. Vet. Bras. 29:919-924. 
Baal D.M. \& Hoveland C.S. 1978. Alkaloid levels in Phalaris aquatica L. as affected by environment. Agronomy J. 70:977-981.

Binta M.G. \& Mushi E.Z. 2012. Environmental factors associated with nitrate poisoning in livestock in Botswana. J. Pet Environ. Biotechnol, 3:6.

Botha C.J. \& Penrith M.L. 2008. Poisonous plants of veterinary and human importance in southern Africa. J. Ethnopharmacol. 119:549-558.

Burrows G.E. \& Tyrl R.J. 2001. Asteraceae, p.214-218. In: Ibid. (Eds), Toxic Plants of North America. Iowa State University Press, Ames.

Callaway T.R., Edrington T.S., Rychlik J.L., Genovese K.J., Poole T.L., Jung Y.S., Bischoff K.M., Anderson R.C. \& Nisbet D.J. 2003. Ionophores: their use as ruminant growth promotants and impact on food safety. Curr. Issues Intest. Microbiol. 4(2):43-51.

Campero C.M. 1996. Efectos de la festuca tóxica sobre el desempeño reproductivo y producción en bovinos: una revisión. Therios 25:132.

Cantón G.J., Campero C.M., Villa M. \& Odriozola ER. 2010. Acute and chronic nervous signs in cattle associated with Phalaris angusta poisoning in Argentina. Pesq. Vet. Bras. 30(1):63-66.

Cole R.J., Dorner J.W., Lansden J.A., Cox R.H., Pape C., Cunfer B., Nicholson S.S. \& Bedell D.M. 1977. Paspalum staggers: isolation and identification of tremorgenic metabolites from sclerotia of Claviceps paspali. J. Agric. Food Chem. 25:1197-1201.

Cullen J.M. \& Stalker M.J. 2016. Liver and biliary system, p.342-343. In: Maxie M.G. (Ed.), Jubb, Kennedy and Palmer's Pathology of Domestic Animals. Vol.2. 6th ed. Elsevier.

Dingley J.M. 1962. Pithomyces chartarum, its occurrence, morphology and taxonomy. N.Z. J. Agric. 5:49-61.

Gimeno E.J. 2001. Calcinosis enzoótica en rumiantes: un problema vigente de la ganadería nacional. Anales de la Academia Nacional de Agronomía y Veterinaria LIV:207-232, 2001.

Jessep T.M., Dent C.H., Kemp J.B., Christie B., Ahrens P.J., Burgess L.W. \& Bryden W.L. 1987. Bovine idiophatic hyperthermia. Aust. Vet. J. 64:353354.

Johnson M.K. 1975. Organophosphorus esters causing delayed neurotoxic effects. Arch. Toxicol. 34:259-258.

Kellerman T.S., Prozesky L., Schultz R.A. \& Rabie C.J. 1993. Neuromycotoxicoses of livestock on pastures in South Africa, with special reference to diplodiosis. N.Z. Vet. J. 41:212-213.

Meerdink G.L. 1989. Organophosphorus and carbamate insecticide poisoning in large animals. Vet. Clin. North Am., Food Anim. Pract. 5(2):375389.

Micheloud J.F., Rodriguez A.M., Cámpora L., Webber N., Campero C.M. \& Odriozola E.R. 2012. Caso inusual de calcinosis enzoótica por el consumo de Solanum glaucophyllum en un encierre a corral. Reva Med. Vet. 93(3/4):59-62.

Micheloud J.F. \& Odriozola E.R. 2012. Actualización sobre la intoxicación por Wedelia glauca (Ort.) Hoffm. Ex. Hicken., Asteraceae. Revta FAVE, Cienc. Vet., 11(1/2):31-39.

Nelly W.R. 1985. The liver and biliary system, p.288-303. In: Jubb K.V.F., Kennedy P.C. \& Palmer N. (Eds), Pathology of Domestic Animals. Vol.2, 3rd ed. Academic Press, New York.

Odriozola E., Campero C., López T., Marin R., Casaro G. \& Andrada M. 1991. Neuropathological effects and deaths of cattle and sheep in Argentina from Phalaris angusta. Vet. Hum. Toxicol. 33:465-467.

Odriozola E., Campero C., Casaro A., Lopez T., Olivieri G. \& Melucci O. 1994. Pyrrolizidine alkaloidosis in argentinian cattle caused by Senecio selloii. Vet. Human Toxicol. 36(3):205-208.

Odriozola E., Bretschneider G., Pagalday M., Odriozola H., Quiroz J. \& Ferreria J. 1998. Intoxicación natural con Cynodon dactylon (pata de perdiz) en un rodeo de cría. Vet. Argentina 148:579-583.

Odriozola E., Odeón A., Cantón G., Clemente G. \& Escande A. 2005. Diplodia maydis: a cause of death of cattle in Argentina. N. Z. Vet. J. 53(2):160161.

Oliveira-Filho J.C., Carmo P.M.S., Pierezan F., Tochetto C., Lucena R.B., Rissi
D.R. \& Barros C.S.L. 2010. Intoxicação por organofosforado em bovinos no Rio Grande do Sul. Pesq. Vet. Bras. 30(10):803-806.

Porter J.K. \& Thompson F.N. 1992. Effects of fescue toxicosis on reproduction in livestock. J. Anim. Sci. 70:1594-1603.

Porter J.K. 1995. Analysis of endophyte toxins: Fescue and other grasses toxic to livestock. J. Anim. Sci. 73(3):871-880.

Potter E.L., VanDuyn R.L. \& Cooley C.O. 1984. Monensin toxicity in cattle. J. Anim. Sci. 58(6):1499-1511.

Radostits O.M., Gay C.C., Hinchcliff K.W. \& Constable P.D. 2007a. Organo phosphorous compounds and carbamates (organophos-phates), p.1834-1837. In: Ibid. (Eds), Veterinary Medicine. 10th ed. W.B. Saunders, Philadelphia.

Radostits O.M., Gay C.C., Hinckcliff K.W. \& Constable P.D. 2007b. Poisoning by micotoxins: Ergot alkaloids: Claviceps purpurea, p.1901-1903. In: Ibid. (Eds), Veterinary Medicine 10th ed. W.B. Saunders, Philadelphia.

Rearte D. 2007. La Producción de Carne en Argentina. Programa Nacional de Carnes. Editora Instituto Nacional de Tecnología Agropecuaria, Buenos Aires, Argentina.

Riet-Correa F., Méndez M.C. \& Schild A.L. 1993. Intoxicacões por Plantas e Micotoxicoses em Animais Domésticos. Agropecuaria Hemisferio Sur, S.R.L

Riet-Correa F. \& Medeiros R. 2000. Toxic plants for ruminants in Brazil and Uruguay: economic impact, control measures and public health implications. XXI World Buiatrics Congress, Punta del Este. Proceedings-in CD-ROM, 2000. p.1201-1212.

Riet-Correa F. \& Medeiros R.M.T. 2001. Intoxicações por plantas em ruminantes no Brasil e no Uruguai: importância econômica, controle e riscos para a saúde pública. Pesq Vet Bras. 21(1):38-42.

Riet-Correa F., Medeiros R.M.T., Pfister J., Schild A.L. \& Dantas A.F.M. 2009. Poisoning by Plants, Mycotoxins and related Substances in Brazilian Livestocks. UFCG, Campina Grande/PB. 246p.

Riet-Correa F., Rivero R., Odriozola E., Adrien M.L., Medeiros R.M.T. \& Schild A.L. 2013. Mycotoxicoses of ruminants and horses. J. Vet. Diagn. Invest. 20(1):1-17.

Rivero R., Matto C., Adrien M.L. \& Rampoldi O. 2011a. Intoxicação por organoclorados (endosulfan) em bovinos no Uruguai. Pesq. Vet. Bras. 31(4):277-280.

Rivero R., Riet-Correa F., Dutra F. \& Matto C. 2011b. Toxic plants and mycotoxins affecting cattle and sheep in Uruguay, p.25-34. In: Riet-Correa F., Pfister J., Schild A.L. \& Wierenga T.L. (Eds), Poisoning by Plants, Mycotoxins, and related Toxins. CAB, London.

Schneider D.J., Miles C.O., Garthwwaite I., Van Halderen A., Wessels J.C. \& Lategan H.J. 1996. First report of field outbreaks of ergot-alkaloid toxicity in South Africa. Onderstepoort J. Vet. Res. 62:97-108.

Sousa R.S. \& Irigoyen L.F. 1999. Intoxicação experimental por Phalaris angusta (Gramineae) em bovinos. Pesq. Vet. Bras. 19(3/4):116-122.

Späth E.J.A. \& Becker B.E. 2012. Análisis epidemiológico de 8 años de diagnósticos de enfermedades de los bovinos. Boln Téc. 160, INTA, Balcarce, Argentina.

Stalker M.J. \& Hayes M.A. 2007. Liver and biliary system, p.368-381. In: Maxie M.G. (Ed.), Jubb, Kennedy and Palmer's Pathology of Domestic Animals. 5th ed. Elsevier, Philadelphia, PA.

Towers N. 1994. Eczema Facial. En: XXII Jornadas Uruguayas de Buiatria. G.1-G.9.

Towers N.R. 2006. Mycotoxin poisoning in grazing livestock in New Zealand. Proc N.Z. Soc. Anim. Prod. 66:300-306.

Uhlig S., Botha C.J., Vrålstad T., Rolén E. \& Miles C.O. 2009, Indole-diterpenes and ergot alkaloids in Cynodon dactylon (Bermuda grass) infected with Claviceps cynodontis from an outbreak of tremors in cattle. J. Agric. Food Chem. 57:11112-11119.

Van Vleet J.F., Amstutz H.E., Weirich W.E., Rebar A.H. \& Ferrans V.J. 1983. Clinical, clinicopathologic, and pathologic alterations in acute monensin toxicosis in cattle. Am. J. Vet. Res. 44(11):2133-2144. 